\title{
PJIEE
}

Premise : Journal of English Education and Applied Linguistics

https://fkip.ummetro.ac.id/journal/index.php/english

Nopikasari,Safitri, and Suhadi

\section{ANALYSIS WORD CLASSES IN SELECTED POEMS BY ALLAN ALEXANDER MILNE \\ By}

\author{
Nora Nopikasari ${ }^{1}$ \\ ${ }^{I}$ The Student of English Study Program in Muhammadiyah University of Bengkulu \\ noranopikasari@gmail.com \\ Ani Safitri ${ }^{1}$ \\ ${ }^{I}$ The Student of English Study Program in Muhammadiyah University of Bengkulu \\ anisa97f@gmail.com \\ Agung Suhadi ${ }^{2}$ \\ ${ }^{2}$ The Lecturer in Muhammadiyah University of Bengkulu \\ agungketupat@yahoo.com
}

Received: January 27, 2018

Revised: January 29, 2018

Accepted: May 2, 2018
Reviewed: January 28, 2018

Reviewed: February 4, 2018

Published: October 1, 2018

\begin{abstract}
:
The objectives of this study are to investigate the word class or known as part of speech from the chosen poems of Alan Alexander Milne. For that reason, five poems of him are analyzed: Wrong House, Furry Bear, If I Were King, The Mirror, dan Hoppity. This study applies descriptive qualitative methods. The procedure of the study covers several steps; dividing words into word class category, analyzing them statistically and reporting the result. Out of the five analyzed poems, there are three-word class categories; verb, noun, an adjective. The most dominant used word class in the poems is noun comprising of 105 in total. This is due to the fact that noun is what the students most widely learned as beginner learners. In these poems, the noun describes the meaning of the poems. Therefore; the categorizing of the part of speech is important to enrich vocabulary and ease the understanding of the poem. This analysis is to make the readers easier in understanding the word class using a poem by Alan Alexander Milne. Keywords: Allan Alexander Milne; noun; poem; word class
\end{abstract}

\section{INTRODUCTION}

Richard, at all (1985, p.209) said that parts of speech (word classes) are a traditional term to describe the different types of word that are used to form sentences. Trask (1999,p.224), Part of speech (word classes) is anyone of the grammatically characterized classes into which the words of a language are grouped. Croft (2001,p.63) writes "Noun, verb, and adjective are not categories of particular languages but noun, verb, and adjective are language universal-that is, there are typological prototype which should be called noun, verb, and adjective'. The fact that major words classes such as verbs, nouns, and adjectives can be identified in almost all languages suggests that there are universal patterns in human cognition that make 
the division into these classes particularly useful for communication, Dixon (2004) If the basic communicative function of a noun is to express a referent and names identify a unique referent, why then does not everything have a name, It would seem that if every object had a name, this would eliminate many ambiguities, Kemp and Regier (2012). Therefore, understanding and identifying word classes is important to form sentences, and the main word classes should be understood are noun, verb, adjective and adverb. Because of that learning and identifying word classes in poetry is interesting and effective way. Poetry is the record of the best and happiest moment of the best and happiest mind, Percy Bysshe Shelley (1821).

Poetry is rhythmical composition of words expressing an attitude to surprise and delight, and arouse an emotional response Kennedy (2005,p.40). Samuel Taylor Coleridge suggests the poem is words of the most beautiful. Poet choose appropriate words and arranged as well as possible, for example a balance symmetrical, between one element with another elements is very close to do, and so on. Poetry is rhythmical creation of beauty in words (Edgar Allan Poe). Poetry is when an emotion has found its thought and the thought has found words (Robert Frost). According to these theories poetry is using beautiful and interesting words, so words in poetry are easy to identify word classes.

Poetry is one of the short and short literary work that contain phrases the hearth, minds and feeling of composed authors poured with utilizing all the power of language in a solid, creative, any imaginative by freely it can said poetry is a brief, dense, dense essay Suroto (1989,p.40). As mentioned above poetry is short literary work, so it is shorter than short story and novel but it includes all familiar word classes.

We choose selected poems by Allan Alexander Milne because he is one of the most famous poets of the 20th century. His poems are not too long and vocabulary is familiar, because his poetry is suitable for children. Finally, there are many words repeated, so it did not need too much time to classify into word classes.

The fact that major words classes such as verbs, nouns, and adjectives can be identified in almost all languages suggests that there are universal patterns in human cognition that make the division into these classes particularly useful for communication (Dixon 2004). The structure of communication is subject to the same cognitive constraints as thinking and problem solving in general. Therefore, it is reasonable that the structure of language, at least to some extent, is determined by such general cognitive principles. In particular, we assume that the structure of language is governedby the the same principles of processing efficiency of representations as are other cognitive processes.

A word class is "a set of words that display the same formal properties, especially their inflections and distribution."(Kolln \& Funk, 2008). To observe the three terms noun, verb and adjective are used universally and uniformly in every line's poetry. The general term word-class that is used here is not nearly as widespread. Alternative terms with considerable currency are part of speech and lexical category.

Syntactic category has been used for classes of constituents (from the word level to the sentence level) since Chomsky (1957), Rauh (2010). However, nouns, verbs and adjectives were not considered an interesting issue in generative linguistics for the first few decades; it was simply assumed by almost everyone that all languages have them. In Croft (1991), the term syntactic category is used for nouns, verbs and adjectives in a typological context. Since the 1990s, the terminal-node categories have generally been divided into functional categories and lexical categories, so nouns, verbs and adjectives came to be known as lexical categories Davis \& Matthewson (1999), Baker (2003), Chung( 2012). 
P. Gärdenfors, A Semantic Theory of Word Classes 181 ties, especially concerning inflections and distribution in sentences. I do not believe in a universal definition of word classes (Croft 2001,p.3). Syntactic structure, including the division into word classes, is language-specific. However, one can identify prototypical structures among words that can be used in classifications. Croft $(2001, p .63)$ writes: "Noun, verb, and adjective are not categories of particular languages, but they are language universal - that is, there are typological prototypes ... which should be called noun, verb, and adjective." In contrast, my position is that the syntactic markers have evolved as effects of the divisions of words into categories, not as causes.

Because, of these theories the researches just focused on these three main word classes namely noun, verb, and adjective. Every lines in this selected poems always consist of this main word classes. Therefore, understanding word classes in poetry is very needed.

Therefore, this study to explore the word classes or kind of word classes and which one is the most dominant word class in these selected poem by Allan Alexander Milne. The purpose of this study to identify word classes, to make easy to arrange correct sentence through understanding word classes from selected poems by Allan Alexander Milne, and can be mastery to write English poetry through understanding word classes.

\section{METHODOLOGY}

\section{Design}

This research used descriptive method, because it is suitable to analyze word classes in selected poems from Allan Alexander Milne's. Descriptive research can be explained as a statement of affairs as they are at present with the researcher having no control over variable. Ethridge, D.E (2004,p.24).

In its essence, descriptive studies are used to describe various aspects of the phenomenon. In its popular format, descriptive research is used to describe characteristics and/or behavior of sample population. Three main purposes of descriptive studies can be explained as describing, explaining and validating research findings. Advantages of using descriptive method are effective to analyze nonquantified topics and issues. The possibility to observe the phenomenon in a completely natural and unchanged natural environment The opportunity to integrate the qualitative and quantitative methods of data collection. Finally it is less time-consuming (John Dudovskiy,2018)

\section{Subject}

The subject in this study is some selected poems by Allan Alexander Milne. Thus, in this research we focused on analyzed three main word classes in selected poems by him as object of the study.

\section{Data and Source of Data}

The data of this study were taken from some sources and journals related to the title of this research, and they are about word classes, poetry, and poetry from Allan Alexander Milne. 


\section{Data Collecting Technique}

The first step is choosing 30 journals that most related to this research and choosing five poetries from Allan Alexander Milne. Then reading all theories in 30 journals and reading the poetry carefully. Finally, the last step is identifying the data. The researchers identify the most related theories in this research, and identify each poetry to poem verse.

\section{Data Analysis Technique}

Then the main phase is analyzing the data, and in this phase consists of five steps. The first is making table kind of word classes consist of noun, verb, adjective, and adverb. Second, input all of poems verse into the table. Third identifying words in poems verse into word classes. Fourth is calculating all of words in word classes and determining which kind the most dominant word class in these selected poems. Then based on the procedure in descriptive method after we got the data, then we described, explained, and validated all of the data that we had analyzed Finally, the last one is drawing conclusion.

\section{Result}

\section{RESULT AND DISCUSSION}

There are five poems by Allan Alexander Milne had analyzed namely The Wrong House, Furry Bear, The Mirror, Hoppity, and If I Were King. Then there are three main word classes had analyzed in these selected poems namely noun, verb, and adjective. These are the tables of result:

\section{Wrong House}

\begin{tabular}{|c|c|c|c|}
\hline Stanza & Verb & Noun & Adjective \\
\hline \multirow{8}{*}{$\begin{array}{l}\text { Stanza } 1 \\
\text { I went into a house, and it } \\
\text { wasn't a house, } \\
\text { It has big steps and a great big } \\
\text { hall; } \\
\text { But it hasn't got a garden, } \\
\text { A garden, } \\
\text { A garden, } \\
\text { It isn't like a house at all. }\end{array}$} & Went & House & Big \\
\hline & Wasn't & House & Big \\
\hline & $\begin{array}{l}\text { Has/ } \\
\text { Hasn't }\end{array}$ & House & Great \\
\hline & Got & Hall & \\
\hline & Isn't & Garden & \\
\hline & Like & Garden & \\
\hline & & Garden & \\
\hline & & Steps & \\
\hline \multirow{7}{*}{$\begin{array}{l}\text { Stanza } 2 \\
\text { I went into a house, and it } \\
\text { wasn't a house, } \\
\text { It has a big garden and great } \\
\text { high wall; } \\
\text { But it hasn't got a may-tree, } \\
\text { A may-tree, } \\
\text { A may-tree, } \\
\text { It isn't like a house at all. }\end{array}$} & Went & House & Big \\
\hline & Wasn't & House & Great \\
\hline & $\begin{array}{l}\text { Hasn't/ } \\
\text { Has }\end{array}$ & House & High \\
\hline & Got & May & \\
\hline & Isn't & May & \\
\hline & Like & May & \\
\hline & & Tree & \\
\hline
\end{tabular}




\begin{tabular}{|c|c|c|c|}
\hline & & Tree & \\
\hline & & Tree & \\
\hline & & Garden & \\
\hline & & Wall & \\
\hline$\checkmark \quad$ Stanza 3 & Went & House & Slow \\
\hline I went into a house, and it & Wasn't & House & White \\
\hline wasn't a house - & Fall & House & \\
\hline may-tree fall: & Got & Petals & \\
\hline But it hasn't got a blackbird, & Isn't & Blackbird & \\
\hline A blackbird, & Like & Blackbird & \\
\hline A blackbird, & Hasn't & Blackbird & \\
\hline It isn t like a house at all. & & May & \\
\hline & & Tree & \\
\hline$\checkmark \quad$ Stanza 4 & Went & House & \\
\hline I went into a house, and I & Was & House & \\
\hline thought it was a house, & Hear & May & \\
\hline the blackbird call & Call & Tree & \\
\hline But nobody listened to it, & Liked & Blackbird & \\
\hline Nobody & Thought & Nobody & \\
\hline Liked it, & Could & Nobody & \\
\hline & Listened & Nobody & \\
\hline & Wanted & & \\
\hline Total & 30 & 36 & 8 \\
\hline
\end{tabular}

Based on the table above, this poetry is dominated by three main word classes namely verb, noun, and adjective. It consists of 30 verbs, 36 nouns, and 8 adjectives. Second, there are many words repeated almost in all of word classes. For instance in verbs namely went, was, and got, they are repeated more than three times. Then, in nouns namely house, garden, and tree, they are repeated in four times. Next in adjective namely big and great, they are repeated two times. In addition this poetry consists of simple word such as got, went, tree, garden, big, great, etc. Last the most dominant word class in this poetry is noun namely 36 words.

This poetry is dominated by three word classes namely verb, noun, and adjective, because they are as the main word classes to form a sentence. Then there are many repeated and simple words in this poetry. It is because this poetry intended for children, and the children's vocabularies are limited. Finally the most dominant word class in this poetry is noun. It is because there are many nouns such as house, garden, tree, etc.

\section{The Mirror}

\begin{tabular}{|l|l|l|l|}
\hline \multicolumn{1}{|c|}{ Stanza } & \multicolumn{1}{c|}{ Verb } & \multicolumn{1}{c|}{ Noun } & \multicolumn{1}{c|}{ Adjective } \\
\hline$\checkmark \quad \begin{array}{l}\text { Stanza 1 } \\
\text { Between the woods the afternoon }\end{array}$ & Lies & The woods & Golden \\
\cline { 2 - 4 } & Saw & Swoon & Silent \\
\hline
\end{tabular}




\begin{tabular}{|c|c|c|c|}
\hline \multirow{9}{*}{$\begin{array}{l}\text { Its fallen in a golden swoon. } \\
\text { The sun looks down from quiet } \\
\text { skies } \\
\text { To where a quiet waater lies, } \\
\text { And silent trees stoop down to } \\
\text { the trees. } \\
\text { And there I saw a white swan } \\
\text { make } \\
\text { Another white swan in the lake, } \\
\text { And, breast to breast, both } \\
\text { motionless, } \\
\text { They waited for the wind's } \\
\text { caress... } \\
\text { And all the water was at ease. }\end{array}$} & Make & The sun & Down \\
\hline & Breast & Caress & White \\
\hline & Waited & Water & White \\
\hline & Looks & Trees & Motionless \\
\hline & Stoop & Swan & Quiet \\
\hline & & Lake & Quiet \\
\hline & & The wind's & \\
\hline & & Skies & \\
\hline & & Ease & \\
\hline Total & 7 & 11 & 8 \\
\hline
\end{tabular}

Based on the table above, this poetry is dominated by three word classes namely verb, noun, and adjective. It consists of 7 verbs, 11 nouns, and 8 adjectives. Second, there are just two repetition words namely white and quiet, and both of them are adjectives. Thus there is no repetition word in verb or noun. However the most dominant word class in this poetry is noun namely 11 words.

This poetry is dominated by three word classes namely verb, noun, and adjective, because they are as the main word classes to form a sentence. Then there are less repetition words in this poetry. It is because this poetry just consists of one stanza, so the words are more variety. Nevertheless this poetry still use simple word namely lies, saw and make, water, trees, and lake, etc. Therefore, even though there are less repeated words in this poetry, it is still suitable for children to understand the meaning of this poetry. However the most dominant word class in this poetry is noun. It is because many nouns such as sun, water, trees skies, etc. refer to the title of this poetry itself. This poetry describes about noun namely The Mirror.

\section{Hoppity}

\begin{tabular}{|c|c|c|c|}
\hline Stanza & Verb & Noun & Adjective \\
\hline \multirow{6}{*}{$\begin{array}{l}\text { Stanza 1 } \\
\text { Christopher Robin goes, } \\
\text { Hoppity, hoppity, } \\
\text { Hoppity, hoppity, hop. } \\
\text { When ever I tell him. } \\
\text { Politely to stop it, he. } \\
\text { Says he can't possibly stop. }\end{array}$} & Goes & Hoppity & \\
\hline & Tell & Hoppity & \\
\hline & Says & Hoppity & \\
\hline & Stop & Hoppity & \\
\hline & Stop & Hop & \\
\hline & & & \\
\hline \multirow{7}{*}{$\begin{array}{l}\text { Stanza } 2 \\
\text { If he stopped hopping. } \\
\text { He couldn't go anywhere, } \\
\text { Poor little Christopher } \\
\text { Couldn't go anywhere... } \\
\text { That's why he alwayas goes } \\
\text { Hoppity, hoppity, }\end{array}$} & Stoped & If & Poor \\
\hline & Go & Hoppity & Little \\
\hline & Go & Hoppity & \\
\hline & Goes & Hoppity & \\
\hline & & Hoppity & \\
\hline & & Hop & \\
\hline & & Hopping & \\
\hline
\end{tabular}




\begin{tabular}{|l|c|c|c|}
\hline $\begin{array}{l}\text { Hoppity, } \\
\text { Hoppity, } \\
\text { Hop }\end{array}$ & & & \\
\cline { 2 - 4 } & & & \\
\cline { 2 - 4 } Total & $\mathbf{9}$ & $\mathbf{1 2}$ & $\mathbf{2}$ \\
\hline
\end{tabular}

Based on the table above, this poetry is dominated by three word classes namely verb, noun, and adjective. It consists of 9 verbs, 12 nouns, and 2 adjectives. Second, there are several words repeated especially in verb and noun. For instance in verbs namely stop and go, they are repeated three times. Then, in nouns namely hoppity, it is repeated eight times. Next in adjective, there is no repetition word. In addition this poetry also consists of simple words namely tell, say, stop, if, poor little, etc. Last the most dominant word class in this poetry is noun namely 12 words.

This poetry is dominated by three word classes namely verb, noun, and adjective, because they are as the main word classes to form a sentence. Then there are several words repeated in this poetry. They are especially in noun for word hoppity, while there is no repetition word in adjective. It is because this poetry consists of less adjective namely just two words. In addition this poetry also consists of simple words for instance says, tell, go, if, little, etc. Then this poetry is intended for children. Thus the poet used repeated and simple words, because the children's vocabularies are limited. Finally the most dominant word class in this poetry is noun. It is because nouns hoppity repeated till eight times refer to the title of this poetry itself. This poetry describes about noun namely Hoppity.

\section{Furry Bear}

\begin{tabular}{|c|c|c|c|}
\hline Stanza & Verb & Noun & Adjective \\
\hline \multirow{8}{*}{$\begin{array}{l}\checkmark \text { Stanza } 1 \\
\text { If I were a bear } \\
\text { And a big bear too, } \\
\text { I shouldn't much care } \\
\text { If it froze or snew; } \\
\text { I shouldn't much mind } \\
\text { If it snowed or friz- } \\
\text { I'd be all fur-lined } \\
\text { With a coat like his! }\end{array}$} & Were & Bear & Big \\
\hline & Shouldn't & Bear & Much \\
\hline & Shouldn't & Care & Fur \\
\hline & Froze & Mind & \\
\hline & Snew & Lined & \\
\hline & Snewed & Coat & \\
\hline & Friz & & \\
\hline & Like & & \\
\hline \multirow{11}{*}{$\begin{array}{l}\checkmark \text { Stanza } 2 \\
\text { For I'd have fur boots } \\
\text { And a brown fur wrap, } \\
\text { And brown knickers } \\
\text { And a big fur cap. } \\
\text { I'd have a fur muffle-ruff. } \\
\text { To cover my jaws, }\end{array}$} & Have & Boots & Brown \\
\hline & Have & Wrap & Brown \\
\hline & Sleep & Knickers & Brown \\
\hline & & Jaws & Brown \\
\hline & & Mittens & Brown \\
\hline & & Head & Big \\
\hline & & Winter & Big \\
\hline & & Bed & Big \\
\hline & & Cap & $\begin{array}{l}\text { Furry- } \\
\text { down }\end{array}$ \\
\hline & & Cover & Fur \\
\hline & & Paws & Fur \\
\hline
\end{tabular}




\begin{tabular}{|c|c|l|l|}
\hline \multirow{2}{*}{$\begin{array}{l}\text { I'd sleep all the winter } \\
\text { In a big fur bed. }\end{array}$} & & $\begin{array}{l}\text { Muffle- } \\
\text { Ruff }\end{array}$ & Fur \\
\cline { 2 - 4 } & & & Fur \\
\cline { 2 - 4 } & & & Fur \\
\cline { 2 - 4 } & & & Fur \\
\hline Total & $\mathbf{1 1}$ & $\mathbf{1 8}$ & $\mathbf{1 8}$ \\
\hline
\end{tabular}

Based on the table above, this poetry is dominated by three word classes namely verb, noun, and adjective. It consists of 11 verbs, 18 nouns, and 18 adjectives. Second, there are many words repeated in verb, noun, and adjective. For instance in verbs namely should and have, they are repeated two times. Then, in nouns namely bear, it is repeated two times. Next in adjective is most repeated namely fur, brown, and big. Last the most dominant word class in this poetry is balance between noun and adjective namely each 18 words.

This poetry is dominated by three word classes namely verb, noun, and adjective, because they are as the main word classes to form a sentence. Then there are many words are repeated in this poetry especially in noun and adjective namely bear, fur, brown, and brown. In addition this poetry also consists of simple words for instance froze, have, bear, boots, fur, brown, etc. Then this poetry is intended for children. Thus the poet used repeated and simple words, because the children's vocabularies are limited. Finally the there are two most dominant word classes in this poetry namely noun and adjective. All of these dominant refer to the title of this poetry itself. This poetry describes about noun namely Furry Bear.

\section{If I Were King}

\begin{tabular}{|c|c|c|c|}
\hline Stanza & Verb & Noun & Adjective \\
\hline \multirow{4}{*}{$\begin{array}{l}\checkmark \text { Stanza } 1 \\
\text { I often wish I were a King, } \\
\text { And then I could do anything. }\end{array}$} & Were & King & \\
\hline & Wish & Anything & \\
\hline & Could & & \\
\hline & Do & & \\
\hline \multirow{4}{*}{$\begin{array}{l}\text { Stanza } 2 \\
\text { If only I were King of Spain, } \\
\text { I'd take my hat off in the } \\
\text { rain. }\end{array}$} & Were & King & Only \\
\hline & Take & Spain & \\
\hline & & Hat & \\
\hline & & Rain & \\
\hline \multirow{4}{*}{$\begin{array}{l}\checkmark \text { Stanza } 3 \\
\text { If only I were King of } \\
\text { France, } \\
\text { I wouldn't brush my hair for } \\
\text { aunts. }\end{array}$} & Were & King & Only \\
\hline & Wouldn't & France & \\
\hline & Brush & Hair & \\
\hline & & Aunts & \\
\hline \multirow{5}{*}{$\begin{array}{l}\checkmark \text { Stanza } 4 \\
\text { I think, if I were King of } \\
\text { Greece, } \\
\text { I'd push things off the } \\
\text { mantelpiece. }\end{array}$} & Think & King & \\
\hline & Were & Greece & \\
\hline & & Things & \\
\hline & & Mantelpiece & \\
\hline & & & \\
\hline
\end{tabular}




\begin{tabular}{|c|c|c|c|}
\hline \multirow{3}{*}{$\begin{array}{l}\text { Stanza } 5 \\
\text { If I were King of Norroway, } \\
\text { I ask an elephant to stay. }\end{array}$} & Were & King & Undone \\
\hline & Ask & Norroway & \\
\hline & & $\begin{array}{l}\text { Elephant/ } \\
\text { Stay }\end{array}$ & \\
\hline \multirow{4}{*}{$\begin{array}{l}\text { Stanza } 6 \\
\text { If I were King of Babylon,, } \\
\text { I'd leave my button gloves } \\
\text { undone. }\end{array}$} & Were & King & \\
\hline & Leave & Babylon & \\
\hline & & Button & \\
\hline & & Gloves & \\
\hline \multirow{3}{*}{$\begin{array}{l}\checkmark \text { Stanza } 7 \\
\text { If I were King of Timbuctoo, } \\
\text { I'd think of lovely things to } \\
\text { do. }\end{array}$} & Were & King & Lovely \\
\hline & Think & Timbuctcoo & \\
\hline & & Things/Do & \\
\hline \multirow{4}{*}{$\begin{array}{l}\checkmark \text { Stanza } 8 \\
\text { If I were King of anything, } \\
\text { I'd tell the soldiers, "I'm the } \\
\text { King!" }\end{array}$} & Were & King & \\
\hline & Tell & King & \\
\hline & & Soldiers & \\
\hline & & Anything & \\
\hline Total & 21 & 30 & 4 \\
\hline
\end{tabular}

Based on the table above, this poetry is dominated by three word classes namely verb, noun, and adjective. It consists of 21 verbs, 30 nouns, and 4 adjectives. Second, there are many words repeated especially in verb and noun. For instance in verbs namely were and think, they are repeated more than two times. Then, in nouns namely king, anything, and thing, they are repeated two times, and especially king repeated nine times. Next in adjective, there is just one repetition word namely only. In addition this poetry also consists of simple words for instance ask, brush, leave, king, elephants, hair, etc. Last the most dominant word class in this poetry is noun namely 30 words.

This poetry is dominated by three word classes namely verb, noun, and adjective, because they are as the main word classes to form a sentence. Then this poetry is intended for children. Therefore the poet used repeated and simple words, because the children's vocabularies are limited. Finally the most dominant word classes in this poetry is noun. All of these dominant words refer to the title of this poetry itself. This poetry describe about noun namely If I Were King.

\section{Dominant}

These selected poems consist of 225 main word classes. Then these are the distribution of words in three main word classes. The firs is noun with 107 words (or about $47,6 \%$ ). The second place is verb with 78 words (or about $34,7 \%$ ). Then the last place is adjective with 40 words (or about 17,8\%). Therefore from data above the authors can conclude that the most dominant word class in these selected poems is noun.

\section{Discussion}

Noun can be the most dominant word class in these selected poems because of three reasons. First noun describes title, because all of titles in these selected poems describe thing. Therefore using dominant noun refers to the title such as house, hoppity, 
bear, and king. All of these nouns directly describe the titles of these selected poems namely Wrong House, Hoppity, Furry Bear and If I Were King. Second there are many repetition nouns refer to the title such as house, hoppity, bear, and king. These words are repeated for many times. Finally using noun can eliminate many ambiguities meaning in poems. Because the function of a noun is to express a referent and names identify a unique referent, why then does not everything have a name? It would seem that if every object had a name, this would eliminate many ambiguities.(Kemp and Regier 2012). Therefore these selected poems intended for children if the line of poetry is ambiguous, so the children will be probably miss understanding the meaning of these poems. Therefore using many nouns in these poems can facilitate children to understand whole meaning of the poems.

These selected poems are suitable for children because of two reasons. First there are many repetition word in all of the main word classes namely in verb, noun, and adjective. It is very helpful, because children's vocabularies are limited. They will be hardly understand the meaning of poems, if the words are too variety. Therefore repetition word can decrease the variety of words. Finally the children can understand the meaning of poems easily. Second according to Nurgiyantoro (2005,p.312) The use of various forms of language in child poetry is still simpler. Child poetry still looks plain, straightforward. Therefore these selected poems using many simple words and familiar using in daily life. Thus the children do not need open dictionary to find unfamiliar words for them, because they can understand the meaning of word directly. Because of these two reasons, these selected poems are suitable for children.

The word-class analysis in these selected poems can assist poets in poetry writing, since the clarity of word classes will influence the selection and use of appropriate words in writing children's poetry. It is also supported by Mitchell (2003,p.142) he said that as part of children's literature, children's poetry also has identical characteristics with child literature; disclosure of something from the child's glasses. Just as it is with adult poetry, child poetry is also written with a strict selection of words, empowerment of metaphors, and imagery to illustrate imagination, memory, and emotion. Therefore before the poets want to write poetry for children they have to understand word classes first, because it will be influencing in choosing the appropriate words for children's poem. Then according to Coleridge states that poetry is the most beautiful word in the most beautiful arrangement. Therefore choosing appropriate words in children's poem is very needed.

\section{CONCLUSION}

These selected poems namely Wrong House, The Mirror, Hoppity, Furry Bear, and If I Were King consist of three main word classes namely noun, verb, and adjective. Then these selected poems consist of 225 main word classes. Next these are the distribution of words in three main word classes. The firs is noun with 107 words (or about $47,6 \%$ ). The second place is verb with 78 words (or about 34,7\%). Then the last place is adjective with 40 words (or about 17,8\%). Therefore, the most dominant word class in these selected poems is noun. It is because of three reasons namely using many nouns refer to the title, repetition nouns refer to the titles, and using noun can eliminate many ambiguities meaning. Finally these selected poems are suitable for children because consist of less variety words and many simple words. These all can facilitate children understand the meaning of poems easily. 


\section{BIO-PROFILE}

Nora Nopikasari, is a student at English Education Study Program of Muhammadiyah University of Bengkulu. She obtained her senior high school at Vocantional High School 2 Kepahiang in 2015. Her research interests are English language teaching and learning, teacher education and professional development. She can be reached at noranopikasari@gmail.com

\section{BIO-PROFILE}

Ani Safitri, is a student at English Education Study Program of Muhammadiyah University of Bengkulu. She obtained her study as Senior High School from SMAN 1 Ulok Kupai in 2015. Her research interests are English language teaching and learning, teacher education and professional development. She can be reached at anisa97f@gmail.com 2

\section{BIO-PROFILE}

Agung Suhadi, M.A. is lecturer of English Education Muhammadiyah University of Bengkulu. His Research interests are literary studies of teaching literature, feminism, postcolonial. He can be reached at 3 


\section{REFERENCES}

Aguilar, A. \& Amat. (2012). The Role of poetry in the Transmission of Divergent Thinking. Spain: Poet \& Lecturer in Terminology Faculty of Translation and Interpreting (FTI) Autonomous University of Barcelona. Vol. 2, No. 21.

Altikriti, Sahar Farouq. (2001). Speech Act Analysis to Short Stories. Dept. of English Language, Al Isra University, Amman, Jordan. Journal of Language Teaching and Research, Vol. 2, No. 6, pp. 1374-1384.

Aqeel, M, dkk. (2015). Stylistic analysis of Robert Frost's poem stopping by woods on a snowy evening. Pakistan: Department of linguistics, leads university, Lahore. ISSN:2278-4012, volume:4,issue:1.

Bibi R. (2015). The analysis of Marxist philosophy in ajmal khattak'a poem "faisla". University, Multan, Pakistan. Art and Social sciences Journal. http://dx.doi.org/10.4172/2151-6200.1000134.

Batool, S, dkk. (2014). Stylistic analysis of Robert frost's poem: "the road not taken". University of Labore, Sarghoda Campus Pakistan. Journal of ELT and Applied Linguistics (JELTAL) Volume2, Issue-4, ISSN: 2347-6575

Ellis, N. C. (1997). Vocabulary acquisition: Word structure, collocation, grammar, and meaning. In M. McCarthy \& N. Schmidt (Eds.) (1997), Vocabulary: description, acquisition and pedagogy (pp. 122-139). Cambridge: Cambridge University Press

Cariboni, K. ( 2011). Poetry in foreign language teaching aspect of major challenge. Madrid : ICERI, pp. 18-26.

Diril, A. (2017). Activities on using poems in teaching English as a foreign language. International Journal of Language Academy. Vol. 5/4, p. 170/180.

Doddy, Noer I. (2014). Understanding how to analyze poetry and its implication to language teaching: USELL.

Gärdenfors, P. (2014). A Semantic Theory of Word Classes. Cognitive Science. Lund University Sydney Technical University. Croatian Journal of Philosophy. Vol. XIV, No. 41.

Haspelmath, martin. (2012). How to compare major word-classes the word's language. UCLA Working Papers in Linguistics, Theories of Everything. Volume 17, Article 16: 109-130.

Irmawati , Noer Doddy. (2014). Understanding how to Analyze Poetry and its Implication to Language Teaching. Yogyakarta: English Language Teaching PBI S2 Graduate School Ahmad Dahlan University. International Journal on Studies in English Language and Literature (IJSELL). Volume 2, Issue 11, PP

Premise Journal Vo. 7 No 2, October 2018, e-ISSN: 2442-482x, p-ISSN: 2089-3345, page 1-14 
35-45 ISSN 2347-3126 (Print) \& ISSN 2347-3134 (Online) www.arcjournals.org

Iqbal, Huma, dkk. (2014). Stylistic Analysis of the Poem "O Where are you Going" by W. H. Auden. Department of English University of Lahore. International Journal Of Humanities And Social Science. Vol. 4, No. 11.

Janssen, Neils, Dkk (2009). The word class effect in the picture-word interference paradigm. The Quarterly Journal Of Experimental Psychology society. iFirst, $\quad 1 \quad-14 . \quad$ http://www.psypress.com/qjep, DOI:10.1080/17470210903377380.

Khan, R, dkk. (2014). Stylistic analysis of wordsworth's poem "to a butterfly”. Pakistan: Department of English University of Sargodha Sargodha. International Journal Of Academic Research and Reflection, Vol 2, No. 1.

L. Brown, E. (2013). Word Classes in Studies of Phonological Variation: Conditioning Factors or Epiphenomena?. University of Colorado at Boulder: Selected Proceedings of the 15th Hispanic Linguistics Symposium, ed. Chad Howe et al., 179-186. Somerville, MA: Cascadilla Proceedings Project.

Lixin XIA. (2015). An error analysis of the word class: a case study of chinese college students. Guangzhou. China: Guangdong University of Foreign Studies. http://dx.doi.org/10.399/ijet.v10i3.4563.

Naseem, Tahira, dkk. (2009). Multilingual Part-of-Speech Tagging: Two Unsupervised Approaches. Computer Science and Artificial Intelligence Laboratory Massachusetts Institute of Technology 77 Massachusetts Avenue, Cambridge MA 02139. Journal Of Artificial Intelligence Research. 36 (2009) $1-45$.

Recep, U. (2012). Making use of poems to teach English. Turkey: JLTL. 2012-2,75-88.

Rumaria, Choerunnisa, (2015). An Analysis Of Speech Acts In The Dead Poets Society. English Education Department the Faculty Of Languages And Arts State University Of Yogyakarta.

Shawa, WisamAl. (2015). Stylistics Analysis of the Poem 'To A Skylark' By P.B.Shelley. Al Quds Open University, IOSR Journal Of Humanities And Social Science (IOSR-JHSS). Volume 20, Issue 3, Ver. III, PP 124-137 e-ISSN: 22790837, p-ISSN: 2279-0845.www.iosrjournals.org

Singh, J, dkk. (2013). Part of speech tagging of Marathi text using prigram method. International journal of advanced information technology (IJAIT). Vol 3, No 2.

Timuçin, Metin. (2010). Exploring The Language Of Poems: A Stylistic Study. Sakarya University, Turkey, Department of Foreign Languages, mtimucin@sakarya.edu.tr. Novitas-ROYAL (Research on Youth and Language), 4 (2), 129-140.

Premise Journal Vo. 7 No 2, October 2018, e-ISSN: 2442-482x, p-ISSN: 2089-3345, page 1-14 
Tyagi, Ankit. (2015). An analysis of robert frost's poem: "the road not taken". $\mathrm{PhD}$ Scholar, SRM University, Sonepat. "Veda's journal of English Language and Literature-JOELL. 2.4 :66-68.

Penzato, M. (2011). Fan fiction poetry, blogs, and journals: a case study of the connection between extracurricular and academic writing. Elizabeth wardle's fall, ENC1102.

Wardani,A. \& Asmarani, R. (2015). Rhyme, Metre analysis and translation strategies of Sapardi Djoko Damono's poems. Semarang. Faculty of Humanities Dian Nuswantoro University

Yeibo, Eb1. (2011). A discourse-stylistic analysis of mood structures in selected poems of j.p. Clark-bekederemo. Niger delta university faculty of arts, dept. of English and literary studies wilberforce island, bayelsa state. International journal of humanities and social science. Vol. 4, No. 16.

Premise Journal Vo. 7 No 2, October 2018, e-ISSN: 2442-482x, p-ISSN: 2089-3345, page 1-14 